U.S. DEPARTMENT OF THE INTERIOR

U.S. GEOLOGICAL SURVEY

\title{
PRELIMINARY GRAVITY AND MAGNETIC MODELS ACROSS MIDWAY VALLEY AND YUCCA WASH, YUCCA MOUNTAIN, NEVADA
}

\author{
By
}

D.A. Ponce and V.E. Langenheim

1994

Open-File Report 94-572

Prepared in cooperation with the

Nevada Operations Office

U.S. Department of Energy

(Interagency Agreement DE-AI08-92NV10874)

This report is preliminary and has not been reviewed for conformity with U.S. Geological Survey editorial standards or with the North American Stratigraphic Code. Any use of trade, firm, or product names is for descriptive purposes only ant does not imply endorsement by the U.S. Government.

Menlo Park, California 1994 


\section{ABSTRACT}

Detailed gravity and ground magnetic data collected along ten traverses across Midway Valley and Yucca Wash on the eastern flank of Yucca Mountain in southwest Nevada are interpreted. These data were collected as part of an effort to evaluate faulting in the vicinity of proposed surface facilities for a potential nuclear waste repository at Yucca Mountain. Geophysical data show that Midway Valley is bounded by large gravity and magretic anomalies associated with the Bow Ridge and Paintbrush Canyon faults, on the west side of Exile Hill and on the west flank of Fran Ridge, respectively. In addition, Midway Valley itself is characterized by a number of small-amplitude anomalies that probably reflect small-scale faulting beneath Midway Valley.

Gravity and magnetic data across the northwest trending Yucca Wash and the inferred Yucca Wash fault indicate no major vertical offsets greater than $100 \mathrm{~m}$ using a density contrast of 0.2 to $0.3 \mathrm{~g} / \mathrm{cm} 3$ along the proposed Yucca Wash fault. In addition, a broad magnetic high coincides with the approximate location of the hydrologic gradient and proba.bly reflects moderately magnetic Topopah Spring Tuff or lavas in the Calico Hills Formatior.

\section{INTRODUCTION}

Gravity and magnetic investigations of Midway Valley and Yucca Wash were begun as part of an effort to help characterize faulting in Midway Valley and Yucca Wash near proposed surface facilities for a potential nuclear waste repository at Yucca Mountain. Midway Valley trends north for about $6 \mathrm{~km}(4 \mathrm{mi})$ along the east side of Yucca Mountain, whereas Yucca Wash is the largest of a group of northwest-trending washes in the northeastern part of Yucca Mountain. The study area is in the southwest quadrant of the Nevada Test Site (NTS) and is bounded by Crater Flat to the west, Timber Mountain to the north, Jackass Flats to the east, and Amargosa Valley to the south (fig. 1).

\section{ACKNOWLEDGMENTS}

R.F. Sikora, S.C. Kuehn, S.L. Snyder, and R.V. Allen of the U.S. Geological Survey (USGS) assisted in data collection and reduction. 


\section{GRAVITY AND MAGNETIC DATA}

Detailed gravity and magnetic data were collected along ten profiles across Midway Valley and Yucca Wash (fig. 1) (Ponce and others, 1993; Langenheim and others, 1993). Gravity data were reduced using the Geodetic Reference System of 1967 (International Union of Geodesy and Geophysics, 1971) and referenced to the International Gravity Standardization Net 1971 gravity datum (Morelli, 1974, p. 18). Gravity data were reduced to complete Bouguer anomalies for reduction densities of 2.67 and $2.00 \mathrm{~g} / \mathrm{cm}^{3}$ and include earth-tide, instrument drift, free-air, Bouguer, latitude, earth-curvature, and terrain corractions. A Bouguer gravity map of the area is shown in figure 2.

Ground magnetic data with the sensor at $2.4 \mathrm{~m}$ above the surface were also collacted along the ten profiles across Midway Valley and Yucca Wash (fig. 1). Maximum station spacing was 20 paces or about $18 \mathrm{~m}$ while minimum spacing was 1 pace or about $1 \mathrm{~m}$. Locations of magnetic stations between surveyed gravity stations were determined by interpolation using the number of paces and the surveyed distances between the gravity stations. An aeromagnetic map of the study area, flown $120 \mathrm{~m}$ above the ground surface is shown in figure 3 .

\section{GENERAL GEOLOGY}

The geologic units that underlie Midway Valley and Yucca Wash consist of Precambrian and Paleozoic rocks, a series of Miocene ash-flow tuffs interbedded with relativel" thin ashfall and re-worked $t$ uffs, and late Tertiary and $Q$ uaternary surficial deposits. Pre-Cenozoic sedimentary and metamorphic rocks in the study area are predominantly limestone and dolomite, with lesser amounts of argillite, quartzite, and marble (U.S. Geological Survey, 1984). The Paleozoic Devils Gate Limestone, Nevada Formation, and Eleana Formation are exposed in the northeastern part of the study area at Calico Hills (McKay and Williams, 1964). The Lone Mountain Dolomite and the Roberts Mountain Formation were penetrated in drill-hole UE-25p\#1 west of Fran Ridge (fig. 1, p\#1), at depths of 1,244 and 1,667 m, respectively ( $\mathrm{Muller}$ and Kibler, 1984).

The stratigraphic names of the Cenozoic volcanic rock units that occur at Yvcca Mountain are undergoing revision (Sawyer and others, in press), elevating Formation names to Group and Members to Formations. In order to be consistent with future work the provisional changes will be used throughout this report (table 1 ). In ascending order the Cenozoic volcanic units are: (1) older ash-flow tuffs, (2) Lithic Ridge Tuff, (3) Crater Flat Group, (4) Calico Hills Formation, (5) Paintbrush Group, and (6) Timber Mountain Group. The Crater Flat Group is composed of the Tram, Bullfrog, and Prow Pass Tuffs, the Paintbrush Group is composed of the Topopah Spring, Pah Canyon, Yucca Mountain, and Tiva Canyon Tuffs, and the Timber Mountain Group is composed of the Rainier Mesa and Ammonia Tanks 
Tuffs. Northeast of Yucca Wash are exposures of the Volcanics of Fortymile V'ash, which are younger than the tuff sequence exposed at Yucca Mountain.

\section{MIDWAY VALLEY}

Midway Valley is a north-trending valley that extends for about $6 \mathrm{~km}$ along the eastern flank of Yucca Mountain (fig. 1). Midway Valley is bounded by two of the five prominent north-trending down-to-the-west normal faults that characterize Yucca Mountain. The western edge of Midway Valley is delineated by the Bow Ridge fault which is exposed on the western slopes of Exile Hill. The eastern edge of Midway Valley is defined by the Paintbrush Canyon fault which is exposed on the west flank of Fran and Alice Ridges in the central part of the study area and in Paintbrush Canyon in the northern part of the study ares. The total length of the Paintbrush Canyon fault may be as much as $32 \mathrm{~km}$ (Dickerson and Spengler, 1994).

In the central part of Midway Valley, Lipman and McKay (1965) mapped a concealed fault along its entire length, whereas Scott and Bonk (1984) mapped this fault only in the southern part of Midway Valley. Based on gravity, seismic, and electrical evidence this fault was subsequently informally named the Midway Valley fault by Neal (1986) and the Midway Valley feature by Ponce (1993).

North of Yucca Wash, Dickerson and Spengler (1994) found that the Paintbrish Canyon fault dips $41^{\circ}$ to $74^{\circ}$ to the west. In central Paintbrush Canyon a well-developed scarp dips $74^{\circ}$ to the west and dip-slip offset is about $230 \mathrm{~m}$. Strata on either side of the fault in

southern Paintbrush Canyon dip $5^{\circ}$ to $15^{\circ}$ eastward. In addition, they found that the fault is not composed of paired faults with west-dipping strata between them, as did Scott and Bonk (1984) but found instead east-dipping strata adjacent to both sides of the fault. However, graben development and rhombic pull-apart features were observed, especially on the west side of the fault, and these features may be expected to occur in the Midway Valley area as well.

\section{YUCCA WASH}

Yucca Wash is a northwest-trending valley that cuts across the north-south trend of central Yucca Mountain and its major faults. The north-south-trending faults are well documented by geologic mapping, whereas the Yucca Wash fault was inferred by connecting the northern boundaries of a series of discontinuous aeromagnetic highs (Bath e.nd Jahren, 1984). This buried fault presumably extends diagonally across the northern end of Midway Valley and terminates in the vicinity of the Paintbrush Canyon fault (Scott and Bonk, 1984). Geologic mapping indicates that a fault with more than $10 \mathrm{~m}$ vertical cffset of the 
Tiva Canyon Tuff is unlikely to exist along Yucca Wash (Scott and others, 1984), whereas aeromagnetic data suggest at least $70 \mathrm{~m}$ of vertical offset (Bath and Jahren, 1984).

South of Yucca Wash is exposed the typical volcanic tuff sequence that has been penetrated by drill holes at Yucca Mountain. North of Yucca Wash are exposures of postPaintbrush Volcanics of Fortymile Canyon and the Chocolate Mountain Tuff. Jucca Wash is only 2.6 km south of the edge of the Claim Canyon caldera, the source of the Paintbrush Group (Frizzell and Schulters, 1990). Because of its proximity to the caldera, large changes in stratigraphic thicknesses of the volcanic units are possible (C. Fridrich, oral commun., 1994). Gravity data also suggest that a northeast-trending graben is present under Yucca Wash (fig. 2); drill-hole data indicate that pre-Paintbrush units are 50 to $100 \%$ thicker in the area of the gravity low (Fridrich and others, 1994).

Scott and Castellanos (1984) have characterized Yucca Wash as a "shear zone" on the basis of its approximate $45^{\circ}$ strike relative to the dominant north-south trending valleys and faults in the area. Scott and Bonk (1984) interpreted Yucca Wash as a concealed rightlateral strike-slip fault; however, previous geologic maps (Christiansen and Lipman, 1965; Byers and others, 1976) do not indicate the presence of any northwest-trending faults in this area. O'Neill and others (1992) interpret the central part of the wash to be a normal fault connecting the left-stepping Bow Ridge fault with the Solitario Canyon fault. C. Fridrich (USGS, written commun., 1993) suggests that a right-lateral transfer fault exists beneath Yucca Wash. This fault accommodates differential extension between the area southwest of Yucca Wash with the more highly extended region northeast of Yucca Wash.

There are two drill holes in Yucca Wash, UE-25 WT\#6 and UE-25 WT\#16 (fig. 1). UE-25 WT\#6 is located about halfway between profiles YC and YD. UE-25 WT\#16 is almost on the concealed projection of the Bow Ridge fault just south of profile YB. The base of the Topopah Spring Tuff drops from $1197 \mathrm{~m}$ above sea level at UE-25WT\#6 to 885 $m$ above sea-level at UE-25 WT\#16. Thus, the Miocene volcanic beds have an apparent southeasterly dip, dropping at least $175 \mathrm{~m}$ over the approximately $3.3 \mathrm{~km}$ distance between UE-25 WT\#6 and UE-25 WT\#16. (See table 2).

\section{PHYSICAL PROPERTIES}

Sources of rock density information are available from rock sampling, core sampling, density profiling and geophysical logs. Mean densities of more than 400 rock samples from the NTS were summarized by Ponce (1981, table 3), geophysical logs of 40 drill holes were summarized by Nelson and others (1991), and magnetic properites of various volcanic rocks were described by Bath (1968), Bath and Jahren (1984), and Rosenbaum and Snyder (1985). A summary of the physical properties used in the gravity and magnetic models is show $n$ in table 3. 
A density log of well UE-25 WT\#6 (Nelson and others, 1991) shows an average density of about $2.00 \mathrm{~g} / \mathrm{cm}^{3}$, ranging from about $1.75 \mathrm{~g} / \mathrm{cm}^{3}$ to $2.20 \mathrm{~g} / \mathrm{cm}^{3}$. The uppermost $30 \mathrm{~m}$ of the Calico Hills Formation is characterized by lower densities, fluctuating between 1.75 and $2.0 \mathrm{~g} / \mathrm{cm}^{3}$ whereas the Topopah Spring Tuff has an average density of about $2.20 \mathrm{~g} / \mathrm{cm}^{3}$. Densities from a $\log$ of UE-25 WT\#16 also average around $2.00 \mathrm{~g} / \mathrm{cm}^{3}$. The Fah Canyon Tuff has an average density of less than $1.80 \mathrm{~g} / \mathrm{cm}^{3}$; the Topopah Spring Tuff and the Calico Hills Formation, about $2.1 \mathrm{~g} / \mathrm{cm}^{3}$. Density profiling indicates that near-surface material in Yucca Wash and vicinity has a density of about $2.0 \mathrm{~g} / \mathrm{cm}^{3}$ (Langenheim and others, 1993)

The density data described above indicate that there are significant density contrasts between alluvium, zeolitized tuffs, partly-welded tuffs, and welded tuffs that range from about $0.2 \mathrm{~g} / \mathrm{cm}^{3}$ between zeolitized, partly-welded tuffs and welded tuffs and up to about 0.6 $\mathrm{g} / \mathrm{cm}^{3}$ between unwelded and welded tuffs. An average density contrast of about 0.2 to 0.3 $\mathrm{g} / \mathrm{cm}^{3}$ works well for estimating vertical offsets along faults in Midway Valley (Ponce, 1993).

Previous studies have show $n$ that remanent magnetization is responsible for causing most of the magnetic anomalies present within the Nevada Test Site and vicinity (Bath, 1968; Bath and Jahren, 1984). In particular many of the north-south-trending, linear magnetic anomalies are caused by vertical offset of the moderately to highly magnetic Topopah Spring Tuff (Bath and Jahren, 1984). In general, magnetic highs occur over the upthrown block. The values listed in Table 3 are averaged values and do not take into account the widely varying magnetization of some units.

\section{MODELING}

The models presented here represent one set of possible geometries that account for observed gravity and ground magnetic anomalies. The models are not unique solutions, but are are based on geologic mapping, geologic cross-sections, stratigraphic thickness, and physical property measurements. In Midway Valley, the two-dimensional models agree well with mapped geology and stratigraphy determined from drill-hole information. In Yucca Wash, however, the two-dimensional models presented here may not adequately account for the three-dimensionality of the underlying structure. Abrupt changes in stratigraphic thickness resulting from the proximity of the Wash to the Claim Canyon caldera and the lack of control on physical properties of volcanic units exposed northeast of Yucca Wash make the models in Yucca Wash poorly constrained.

\section{MIDWAY VALLEY}

Three gravity and magnetic profiles (G3, G1, and G4) in Midway Valley were modeled. All three models are characterized by gravity and magnetic anomalies associated with the 
block-bounding Bow Ridge and Paintbrush Canyon faults. In addition, the profiles show a lower-amplitude anomaly in the central part of Midway Valley associated with the Midway Valley feature (Ponce, 1993). Gravity and magnetic modeling support geologic models and indicate that these faults are down to the west normal faults with a dip of about $70^{\circ}$. However, the models presented here are preliminary and are based on the 'average' physical properties (table 3 ) derived from physical property measurements. Representative density contrasts and magnetic properties were assigned to entire units, rather than to individual cooling units for example, because of insufficient data. In addition, gravity and magnetic models may not exactly correlate to one another because the density and magnetic property distribution may not reflect the same geologic boundaries.

Profile G3, in the southernmost part of Midway Valley is dominated by the geophysical expression of the Midway Valley feature and the Paintbrush Canyon fault immediately to the east (fig 4). The combined gravity and magnetic model of profile G3 is structurally controlled by drill hole p\#1, just south of the line (fig. 1), and is the only drill hole to reach Paleozoic rocks in the Yucca Mountain area. Gravity data reveal a $0.6 \mathrm{mGal}$ (milligal) anomaly associated with the Midway Valley fault and a $1.9 \mathrm{mGal}$ anomaly assoriated with the Paintbrush Canyon fault. Magnetic data show a $80 \mathrm{nT}$ (nanoteslas) and $150 \mathrm{n} \mathrm{T}$ anomaly associted with the Midway Valley and Paintbrush Canyon faults, respectively.

Profile G1, in the central part of Midway Valley, is characterized by the Bow Ridge and Paintbrush Canyon Faults. The model geometry used along profile $\mathrm{G} 1$ is based on several geologic cross-sections including that of Scott and Bonk (1984), Neal (1986), and Buesch and others (1994). In addition, model $\mathrm{G} 1$ is controlled by several drill holes inclrding USW G-4 and UE25b\#1 to the west (Spengler and Chornack, 1984; Lahoud and others, 1984), WT\#14 (table 2) to the south, and a number of shallow drill holes in the vicinity of Exile Hill (Buesch and others, 1994). Gravity and magnetic modeling indicate that the Bow Ridge fault has a vertical offset of about $200 \mathrm{~m}$, whereas the Paintbrush Canyon fault has an offset of about $400 \mathrm{~m}$. The Midway Valley feature is well expressed, particularly in the magnetic data, and suggests that a horst-like structure defined by two faults is present in the central part of Midway Valley each with a vertical offset of about $75 \mathrm{~m}$. This value is similar to the 40 to $60 \mathrm{~m}$ offset determined using gravity data and an infinite vertical fault model with a density contrast of 0.3 to $0.2 \mathrm{~g} / \mathrm{cm}^{3}$ (Ponce, 1993).

Profile G4, in the northern part of Midway Valley is also characterized by the gravity and magnetic signature of the Bow Ridge and Paintbrush Canyon faults. The gravity and magnetic model is controlled by drill hole WT\#4 (fig. 1 and table 2) which has a total depth of 1,580 ft (482 m) and penetrates to the Calico Hills Formation. Gravity data reveal a 1.7 $\mathrm{mGal}$ gravity anomaly associated with the Bow Ridge fault and a $2.2 \mathrm{mGal}$ gravity anomaly associated with Paintbrush Canyon fault. Magnetic data indicate a 60-180 nT anomaly associated with the Bow Ridge Fault and a $320 \mathrm{nT}$ anomaly associated with the Paintbrush Canyon fault. In addition, geophysical data indicate that the Midway Valley featr re extends the entire length of Midway Valley. Along G4, a $0.5 \mathrm{~m} \mathrm{Gal} \mathrm{gravity} \mathrm{anomaly} \mathrm{and} \mathrm{a} 90-180 \mathrm{nT}$ 
magnetic anomaly is associated with this feature. Gravity and magnetic modeling indicate that the vertical offset associated with the Midway feature is about $75 \mathrm{~m}$.

\section{YUCCA WASH}

Three gravity and ground magnetic profiles (YA, YC, and YF) in Yucca Wash were modeled. Although profile YA is at the mouth of Yucca Wash, its structure is more similar to that in Midway Valley. Profile YA shows both gravity ( $2 \mathrm{mGal}$ ) and magnetic (600 $\mathrm{nT}$ ) anomalies associated with the Paintbrush Canyon fault on the eastern part of the profile (fig. 7). The Bow Ridge fault is also well-expressed by about a 0.5 to $0.7 \mathrm{mGal}$ anomaly on the western part of the profile, about $200 \mathrm{~m}$ east of where projected by Scott and Bnnk (1984). The mapped projection of the Yucca Wash Fault is located near a 0.5 to 0.7 mGal gravity anomaly and a $150 \mathrm{nT}$ magnetic anomaly at about $2000 \mathrm{~m}$, but other north-south trending faults located farther south in Midway Valley (Ponce and others, 1993) could be responsible for these geophysical anomalies. A $0.4 \mathrm{mGal}$ anomaly is located along the projertion of the Midway Valley feature. The geometry of the modeled profile is modified from c-oss section A-A' of Lipman and McKay (1965). The gravity and magnetic models indicate about 250 $\mathrm{m}$ of offset on the Paintbrush Canyon fault, $75 \mathrm{~m}$ on the Midway Valley feature, and $100 \mathrm{~m}$ on the Bow Ridge fault. The estimated offsets on these faults are consistent with estimates derived from modeling in Midway Valley.

Profile YC (fig. 8) is characterized by a rather flat gravity signature. Low gravity values at the ends of the profile indicate topographic slopes of low-density rock as low as $1.7 \mathrm{~g} / \mathrm{cm}^{3}$. Rapid changes in magnetic intensity on the easternmost $300 \mathrm{~m}$ of $\mathrm{YC}$ are caus $\mathrm{d}^{\mathrm{d}}$ by close proximity to randomly oriented, strongly magnetic float. The geometry of the modeled YC profile is modified from cross-section D-D' of Scott and Bonk (1984). The ground magnetic highs on the western two-thirds of the profile appear to be related to an aeromagnetic high (Bath and Jahren, 1984) present over Isolation Ridge, a topographic high located southwest of Yucca Wash (fig. 3). The edge of the ground magnetic anomaly on profile YC occurs under the northeastern edge of the wash, not under the alluvial sediments of the wash. The aeromagnetic data suggest that the northeastern edge of the Isolation Ridge anomaly coincides with the inferred extension of the Bow Ridge fault as extended into Yucra Wash by Christiansen and Lipman (1965); however the model suggests that the edge of the magnetic source is offset about $150 \mathrm{~m}$ to the southwest of the inferred location of the Bow Ridge fault. The aeromagnetic data also indicate that the maximum depth to the top of the source of the Isolation Ridge anomaly is about $500 \mathrm{~m}$ (within the Prow Pass Tuff). Although the ground magnetic data are complicated by near-surface noise and do not extend across the width of the low, the data are consistent with the estimate of the maximum depth to the top of the source from the aeromagnetic data. The source of this anomaly according to the model presented here is highly magnetic $(2.5 \mathrm{~A} / \mathrm{m})$ and denser $\left(2.3 \mathrm{~g} / \mathrm{cm}^{3}\right)$ rhyolite lava of 
the Calico Hills Formation. However, the source of the anomaly may be shallow or and thus reside within the Topopah Spring Tuff. Aeromagnetic highs in the Yucca Wash area coincide with outcrops of Topopah Spring Tuff. The Yucca Wash fault, at the location inferred by Scott and Bonk (1984), does not have much, if any, geophysical expression.

Gravity data along YF (fig. 9) indicate a broad, 2-3 $\mathrm{mGal} \mathrm{low,} \mathrm{which} \mathrm{is} \mathrm{part} \mathrm{of} \mathrm{a}$ northeast-trending gravity low interpreted by Fridrich and others (1994) to ba a graben formed before deposition of the Paintbrush Group. The low as modeled along profile YF is the result of thickening of pre-Paintbrush units. The geometry of the modeled profile is modified after the geologic cross-section of Fridrich and others (1994, fig. 11). Superimposed on the broad gravity low is a $0.5 \mathrm{mGal}$ high that coincides with the location of a broad ground magnetic high. Based on the assumption that the source of the magnetic anomaly is the same as that of the gravity anomaly, the source of these anomalies could be denser, more magnetic rhyolite lava of the Calico Hills Formation. Another potential source of these gravity and magnetic anomalies could be a basaltic sill whose top can be no deepor than 500 m.

Profile YF (fig. 9), which runs longitudinally along Yucca Wash, shows a large $(1,000$ $\mathrm{nT}$ ) ground magnetic anomaly just north of UE-25 WT\#6. The maximum depth to the top of the source of this anomaly is about $100 \mathrm{~m}$ based on gradient analysis (Langenheim and Ponce, 1994). Two ground magnetic profiles approximately $100 \mathrm{~m}$ to either side of profile YF also show a large magnetic anomaly at approximately the same location as the anomaly on YF, perhaps indicating little or no (less than $250 \mathrm{~m}$ ) horizontal offset along the proposed Yucca Wash fault. To the south of the 1,000 nT anomaly is a broad 200-300 $\mathrm{nT}$ magnetic high whose source appears to be deeper. Comparison of the ground magnetic data with aeromagnetic data suggests that the broad magnetic high seen on profile YF is related to the Isolation Ridge aeromagnetic high (Bath and Jahren, 1984). Both the ground magnetic and aeromagnetic data suggest that the top of the body or bodies responsible for the magnetic highs can be no deeper than $500 \mathrm{~m}$ and most likely resides within the Calico Hills Formation or Topopah Spring Tuff. This maximum depth based on gradient analysis of the anomalies eliminates alteration of the Eleana formation to be the source of tle Isolation Ridge anomaly as suggested by Bath and Jahren (1984). Topography on the al -1vium-tuff interface alone is not sufficient to produce the sharp magnetic high. According to this model, intense magnetizations in the Topopah Spring Tuff $(4 \mathrm{~A} / \mathrm{m})$ and the Calico Hills Formation ( 5 to $7 \mathrm{~A} / \mathrm{m}$ ) are needed to produce the ground magnetic highs. If the thick ress of the bodies were doubled, the magnetizations would decrease by about half. The source of the change in magnetization could be alteration of the volcanic units or basaltic sills or dikes. The model indicates that the southeastern edge of the source of the broad magnetic high does not coincide with the location of the Bow Ridge fault. 


\section{CONCLUSIONS}

Gravity and magnetic data and models along traverses across Midway Valley and Yucca Wash show prominent anomalies assocated with known faults and reveal a numbe: of possible concealed faults beneath Midway Valley. The Bow Ridge fault and the Paintbrish Canyon fault are the largest gravity and magnetic anomalies in the vicinity of Midway Valley. Geophysical modeling infer a vertical offset of about $100-200 \mathrm{~m}$ for the Bow Ridge fault and about 200-400 $\mathrm{m}$ for the Paintbrush Canyon fault.

The central part of Midway Valley is characterized by several small-amplitude anomalies that probably reflect small-scale faulting beneath Midway Valley. Gravity and magnetic modeling reveals a horst-like feature in the central part of Midway Valley referred to as the Midway Valley feature (Ponce, 1993). This feature is near the concealed fault mapped by Lipman and McKay (1965) and is characterized by a gravity anomaly with an amplitude of about $0.5 \mathrm{mGal}$ and a magnetic anomaly with an amplitude of about 80 to $210 \mathrm{nT}$. Gravity and magnetic modeling infer an offset of about $75 \mathrm{~m}$ for each of the faults that comprise the Midway Valley feature.

Gravity and magnetic studies show that they are useful for delineating major faults at Yucca Mountain such as the Bow Ridge and Paintbrush Canyon faults, and minor faults such as those concealed beneath Midway Valley. Detailed gravity, magnetic, and electrical data could provide an effective means to better define the location of known or suspected faults and to locate concealed or unknown faults.

Gravity and magnetic data across Yucca Wash do not indicate, but do nct preclude, major vertical offsets on the proposed Yucca Wash fault. The broad magnetic high along the longitudinal profiles is intriguing because of its location with respect to the hydrologic gradient. The maximum depth to the source of the high is about $500 \mathrm{~m}$, suggesting that the age of the source must be that of the Prow Pass Tuff (14.0 Ma; Marvin and others, 1970) or younger. If the source of the anomaly is cut by a buried strike-slip fault, the movement of the fault must post-date deposition of the Prow Pass Tuff. Ground magnetic data (Iangenheim and others, 1993) show that the broad magnetic high appears at approximatel" the same location along three longitudinal profiles, perhaps indicating little or no (less than $250 \mathrm{~m}$ ) horizontal offset along a buried strike-slip fault within Yucca Wash since $14.0 \mathrm{Ma}$.

In order to determine the source of the magnetic anomalies in Yucca Wasl, magnetic property measurements of the Topopah Spring Tuff and the Calico Hills Formation are needed. Drill hole USW WT\#6 is the only drill hole within the anomaly; it may have penetrated the top of the source of the Isolation Ridge anomaly (less than $500 \mathrm{~m}$ ) and should have penetrated the source of the large, shallow ground magnetic anomaly. Magnetic property measurements of core samples could determine the source of the anomalies. A ground magnetic profile perpendicular to the northern edge of the Isolation Ridge aeromagnetic anomaly could better locate the edge of the anomaly as well as give a better estimate of the maximum 
depth to the top of the source. Physical property measurements of the post-Paintbrush units exposed northeast of Yucca Wash would help constrain the models presented here. 


\section{REFERENCES}

Bath, G.D., 1968, Aeromagnetic anomalies related to remanent magnetism in volcanic rock, Nevada Test Site, in Eckel, E.B., ed., Nevada Test Site: Geological Society of America Memoir 110, p. 135-146. (N NA.880517.1178)

Bath, G.D., and Jahren, C.E., 1984, Interpretations of magnetic anomalies at a potential repository site located in the Yucca Mountain area, Nevada Test Site: U.S. Geological Survey Open-File Report 84-120, 40 p. (NNA.870323.0194)

Buesch, D.C., Dickerson, R.P., Drake, R.M., and Spengler, R.W., 1994, Integrated geology and preliminary cross section along the north ramp of the Exploratory Studies Facility, Yucca Mountain: American Nuclear Society Proceedings of the Fith Annual International Conference on High-level Waste Management, Las Vegas, Nev., p. 1055-1065. (MOL.19941004.0158)

Byers, F.M., Carr, W.J., Christiansen, R.L., Lipman, P.W., Orkild, P.P., and Quinlivan, W.D., 1976, Geologic map of the Timber Mountain caldera area, Nye County, Nevada: U.S. Geological Survey Miscellaneous Investigations Series Map I-891, scale 1:48,000. (HQS.880517.1107)

Christiansen, R.L., and Lipman, P.W., 1965, Geologic map of the Topopah Spring NW quadrangle, Nye County, Nevada: U.S. Geological Survey Geologic Quadrangle Map GQ-444, scale 1:24,000. (HQS.880517.1118).

Dickerson, R.P., and Spengler, R.W., 1994, Structural character of the northern segment of the Paintbrush Canyon fault, Yucca Mountain, Nevada: American Nuclear Society Proceedings of the Fifth Annual International Conference on High-level Waste Management, Las Vegas, Nev., p. 2367-2372. (MOL.19941004.0159)

Fridrich, C.J., Dudley, W.W., Jr., and Stuckless, J.S., 1994, Hydrogeologic analysis of the saturated-zone ground-water system, under Yucca Mountain, Nevada: Journal of Hydrology, v. 154, p. 133-168. (MOL.19940811.0102)

Frizzell, V.A., and Shulters, Jacqueline, 1990, Geologic map of the Nevada Test Site, southern Nevada: U.S. Geological Survey Miscellaneous Investigations Series M.ap I-2046, scale $1: 100,000$. (NNA.910123.0073)

International Union of Geodesy and Geophysics, 1971, Geodetic Reference System 1967: International Association of Geodesy Special Publication no. 3, 116 p. (NNA.901127.0202)

Lahoud, R.G., and Lobmeyer, D.H., and Whitfield, M.S., Jr., 1984, Geohydrology of volcanic tuff penetrated by test well UE-25b\#1, Yucca Mountain, Nye County, Nevada: U.S. Geological Survey Open-File Report 84-4253, 44 p. (NNA.890511.0117)

Langenheim, V.E., Ponce, D.A., Oliver, H.W., and Sikora, R.F., 1993, Gravity and magnetic data of Yucca Wash, southwest Nevada: U.S. Geological Survey Open-File Report 93586-A, documentation, 22 p., 2 sheets, 1:12,000; 93-586-B, diskette. (NNA.94n510.0001) 
Langenheim, V.E., and Ponce, D.A., 1994, Gravity and magnetic investigations of Yucca Wash, southwest Nevada: American Nuclear Society Proceedings of the Fith Annual International Conference on High-level Waste Management, Las Vegas, Nev., 7 p. (MOL. 19941004.0162)

Lipman, P.W., and McKay, E.J., 1965, Geologic map of the Topopah Spring SW quadrangle, Nye County, Nevada: U.S. Geological Survey Geologic Quadrangle Map GO-439, scale $1: 24,000$. (HQS.880517.1317)

Maldonado, Florian, and Koether, S.L., 1983, Stratigraphy, structure, and some petrographic features of Tertiary volcanic rocks at the USW G-2 drill hole, Yucca Mountain, Nye County, Nevada: U.S. Geological Survey Open-File Report 83-732, 83 p., 1 plate. (NNA.870506.0143)

Marvin, R.F., Byers, F.M., Jr., Mehnert, H.H., Orkild, P.P., and Stern, T.W., 1970, Radiometric ages and stratigraphic sequence of volcanic and plutonic rocks, southern $\mathrm{N}$ ye and western Lincoln counties, Nevada: Geological Society of America Bullotin, v. 81, p. 2657-2676. (NNA.930118.0006)

McKay, E.J., and Williams, W.P., 1964, Geology of the Jackass Flats quadrangle, Nye County, Nevada, U.S. Geological Survey Geologic Quadrangle Map GQ-368, scale 1:24,000. (HQS.880517.0032-1339)

Morelli, C.(Ed.), 1974, The International Gravity Standardization Net, 1971: Irternational Association of Geodesy Special Publication no. 4, 194 p. (NNA.901127.0203)

Muller, D.C., and Kibler, J.E., 1984, Preliminary analysis of geophysical logs from drill hole UE-25p\#1, Yucca Mountain, Nye County, Nevada, U.S. Geological Survey Open-File Report 84-649, 14 p. (SRX.850104.0241)

Neal, J.T., 1986, Preliminary validation of geology at site for repository surface facilities, Yucca Mountain, Nevada: Sandia National Laboratories Report SAND85-0815, Albuquerque, New Mexico. (HQS.880517.2805)

Nelson, P.H., Muller, D.C., Schimschal, Ulrich, and Kibler, J.E., 1991, Geophysical logs and core measurements from forty boreholes at Yucca Mountain, Nevada: U.S. Geological Survey Geophysical Investigations Map GP-1001, 64 p., 10 sheets, 1:1,200. (NNA.920211.0022)

O'Neill, J. Michael, Whitney, John W., and Hudson, Mark R., 1992, Photogeologic and kinematic analysis of lineaments at Yucca Mountain, Nevada: Implications for strikeslip faulting and oroclinal bending: U.S. Geological Open-File Report 91-623, 24 p., scale 1:24,000. (NNA.921211.0174)

Ponce, D.A., 1981, Preliminary gravity investigations of the Wahmonie site, Nevada Test Site, Nye County, Nevada: U.S. Geological Survey Open-File Report 81-522, 64 p. (HQS.880517.2824)

Ponce, D.A. 1993, Geophysical investigations of concealed faults near Yucca Mountain, southwest Nevada: American Nuclear Society Proceedings of the Fourth Annual International Conference on High level Waste Management, v. 1, p. 168-174. (NNA.931025.0028) 
Ponce, D.A., Langenheim, V.E., and Sikora, R.F., 1993, Gravity and magnetic data of Midway Valley, southwest Nevada: U.S. Geological Survey Open-File Report 93-540-A, documentation, 9 p, scale 1:12,000.; 93-540-B, diskette. (NNA.940418.0157)

Rosenbaum, J.G., and Snyder, R.B., 1985, Preliminary interpretation of paloomagnetic and magnetic property data from drill holes USW G-1, G-2, G-3, and VH-1 and surface localities in the vicinity of Yucca Mountain, Nye County, Nevada: U.S. Geological Survey Open-File Report 85-49, 73 p. (NNA.930707.0065)

Sawyer, D.A., Fleck, R.J., Lanphere, M.A., Warren, R.G., Broxton, D.E., ard Hudson, M.R., 1994, Episodic caldera volcanism in the Miocene southwestern Nevada volcanic field: ${ }^{10} \mathrm{Ar} /{ }^{39} \mathrm{Ar}$ geochronologic framework and revised stratigraphy: Geolog:cal Society of America Bulletin, v. 106, p. 1304-1318. (MOL.19940725.0004)

Scott, R.B., and Bonk, Jerry, 1984, Preliminary geologic map of Yucca Mountain, Nye County, Nevada with geologic sections: U.S. Geological Survey Open-File Report 84494, scale 1:12,000. (HQS.880517.1443)

Scott, R.B., and Castellanos, Mayra, 1984, Stratigraphic and structural relations of volanic rocks in drill holes USW GU-3 and USW G-3, Yucca Mountain, Nye County, Nevada: U.S. Geological Survey Open-File Report 84-491, 121 p. (NNA.890804.0017)

Scott, R.B., Bath, G.D., Flanigan, V.J., Hoover, D.B., Rosenbaum, J.G., and Spengler, R.W., 1984, Geological and geophysical evidence of structures in northwest-trending washes, Yucca Mountain, southern Nevada, and their possible significance to a nuclear waste repository in the unsaturated zone: U.S. Geological Survey Open-File Report 84-567, 23 p. (NNA.870519.0101)

Spengler, R.W., and Chornack, M.P., 1984, Stratigraphic and structural characteristics of volcanic rocks in core hole USW G-4, Yucca Mountain, Nye County, Nevada: U.S. Geological Survey Open-File Report 84-789, 77 p. (NNA.890804.0012)

U.S. Geological Survey, 1984, A summary of geologic studies through January 1, 1983, of a potential high-level radioactive waste repository site at Yucca Mountain, southern Nye County, Nevada: U.S. Geological Survey Open-File Report 84-792, 103 p. (NNA.891009.0304)

NOTE: Paren thesized numbers following each cited reference are for U.S. Department of Energy Office of Civilian Radioactive Waste Management Records Management purposes only and should not be used when ordering the publication. 
TABLE 1.-Geologic names and symbols.

Modified from Sawyer and others (in press)

\begin{tabular}{|c|c|}
\hline Name of Unit & Symbol \\
\hline \multicolumn{2}{|l|}{ Quaternary } \\
\hline Alluvium and colluvium & Qac \\
\hline \multicolumn{2}{|l|}{ Miocene $^{1}$} \\
\hline $\begin{array}{l}\text { Volcanics of Fortymile Canyon } \\
\text { Timber Mountain Group } \\
\text { Ammonia Tanks Tuff } \\
\text { Rainier Mesa Tuff } \\
\text { tuff unit "X" }\end{array}$ & $\begin{array}{l}\operatorname{Tfc} \\
\operatorname{Tma} \\
\operatorname{Tm} r \\
\operatorname{Tm} x\end{array}$ \\
\hline $\begin{array}{l}\text { Paintbrush Group } \\
\text { Tiva Canyon Tuff } \\
\text { Yucca Mountain Tuff } \\
\text { Pah Canyon Tuff } \\
\text { Topopah Spring Tuff } \\
\text { Calico Hills Formation }\end{array}$ & $\begin{array}{l}\text { Tpc } \\
\text { Tpy } \\
\text { Tpp } \\
\text { Tpt } \\
\text { Tht }\end{array}$ \\
\hline $\begin{array}{l}\text { Crater Flat Group } \\
\text { Prow Pass Tuff } \\
\text { Bullfrog Tuff } \\
\text { Tram Tuff } \\
\text { Lavas and Flow Breccias } \\
\text { Lithic Ridge Tuff } \\
\text { Older Tuffs }\end{array}$ & $\begin{array}{l}\text { Tcp } \\
\text { Tcb } \\
\text { Tct } \\
\text { Tll } \\
\text { Tlr } \\
\text { Tt }\end{array}$ \\
\hline \multicolumn{2}{|l|}{ Paleozoic } \\
\hline Paleozoic rocks, undifferentiated & $\mathrm{Pz}$ \\
\hline
\end{tabular}

${ }^{1}$ Includes bedded tuff at base of most units 
TABLE 2.-Thickness of rock units in various drill holes ${ }^{1,2}$

\begin{tabular}{|c|c|c|c|c|c|c|c|}
\hline Symbol & G-1 & G-2 & p\# 1 & $\begin{array}{l}\text { Thicknes } \\
\text { WT\#4 }\end{array}$ & $\begin{array}{l}\text { in meters } \\
\text { WT \#6 }\end{array}$ & WT\# 14 & $\mathrm{~W}^{\mathrm{m}} \# 16$ \\
\hline Qac & 18 & - & 39 & 16 & 52 & 37 & 42 \\
\hline $\mathrm{Tfc}$ & - & - & - & - & - & - & - \\
\hline $\operatorname{Tma}$ & - & - & - & - & - & - & - \\
\hline $\mathrm{Tmr}$ & - & - & 16 & - & - & - & - \\
\hline $\mathrm{Tpc}$ & - & 75 & 27 & 71 & - & - & 97 \\
\hline Tpy & 23 & 77 & - & 17 & - & - & - \\
\hline $\mathrm{Tpp}$ & 30 & 80 & - & 29 & - & - & 37 \\
\hline $\mathrm{Tpt}$ & 363 & 304 & 300 & 220 & 65 & 332 & 150 \\
\hline Tht & 115 & 289 & 55 & 130 & 266 & 30 & 195 \\
\hline$T c p$ & 114 & 187 & 122 & - & - & - & - \\
\hline $\mathrm{Tcb}$ & 142 & 89 & 133 & - & - & - & - \\
\hline Tct & 280 & 154 & 182 & - & - & $\ldots$ & - \\
\hline Tll & 118 & 35 & - & - & - & - & - \\
\hline $\mathrm{Tlr}$ & 303 & 193 & 194 & - & - & - & - \\
\hline $\mathrm{Tt}$ & 323 & 258 & 176 & - & - & - & - \\
\hline $\mathrm{P}_{\mathrm{z}}$ & - & - & 562 & - & - & - & - \\
\hline
\end{tabular}

${ }^{1}$ Includes bedded tuff at base of most volcanic units.

${ }^{2}$ Data modified from Maldonado and Koether (1983, table 3) and Spengler (WT-lıgs, written commun., 1994). 
TABLE 3..-Physical properties of rock units used in the models.

Values were derived from borehole samples, borehole logs, and surface samples 1

\begin{tabular}{lrrrc}
\hline Unit & $\begin{array}{r}\text { Declination } \\
\text { deg }\end{array}$ & $\begin{array}{r}\text { Inclination } \\
\text { deg }\end{array}$ & $\begin{array}{c}\text { Magnetization } \\
\text { A } / \mathrm{m}\end{array}$ & $\begin{array}{c}\text { Density } \\
\text { g/cm }\end{array}$ \\
\hline Qac & 0 & 0 & 0.0 & $1.5-1.8$ \\
Tfc & 170 & -30 & 1.9 & $1.8-2.0$ \\
Tma & 0 & 59 & 0.58 & 2.0 \\
Tm r & 168 & -55 & $0.8-2.7$ & $1.5-2.0$ \\
Tmx & 0 & 0 & 0.0 & 2.0 \\
Tpc & 169 & -23 & 0.94 & 2.0 \\
Tpy & 170 & 1 & 0.24 & 1.6 \\
Tpp & 154 & -62 & 1.6 & $1.4-1.9$ \\
Tpt & 322 & 52 & 1.3 & $2.2-2.4$ \\
Tht & 6 & 56 & 0.11 & $1.9-2.0$ \\
Tcp & -4 & 50 & 0.26 & $2.0-2.3$ \\
Tcb & 12 & 41 & 1.7 & $2.2-2.4$ \\
Tct & 131 & -30 & 1.2 & $2.0-2.4$ \\
Tll & 5 & 50 & 1.0 & 2.5 \\
Tlr & 251 & 62 & 0.22 & $2.0-2.4$ \\
Tt & 50 & 60 & 0.3 & 2.4 \\
Pz & 0 & 0 & 0.0 & 2.7 \\
\hline
\end{tabular}

1 Data modified from Rosenbaum and Snyder (1985), Bath and Jahren (1984), and M.R. Hudson (USGS, written commun., 1994)

2 Total declination, inclination, and magnetization

${ }^{3}$ Remanent declination, inclination, and magnetization 


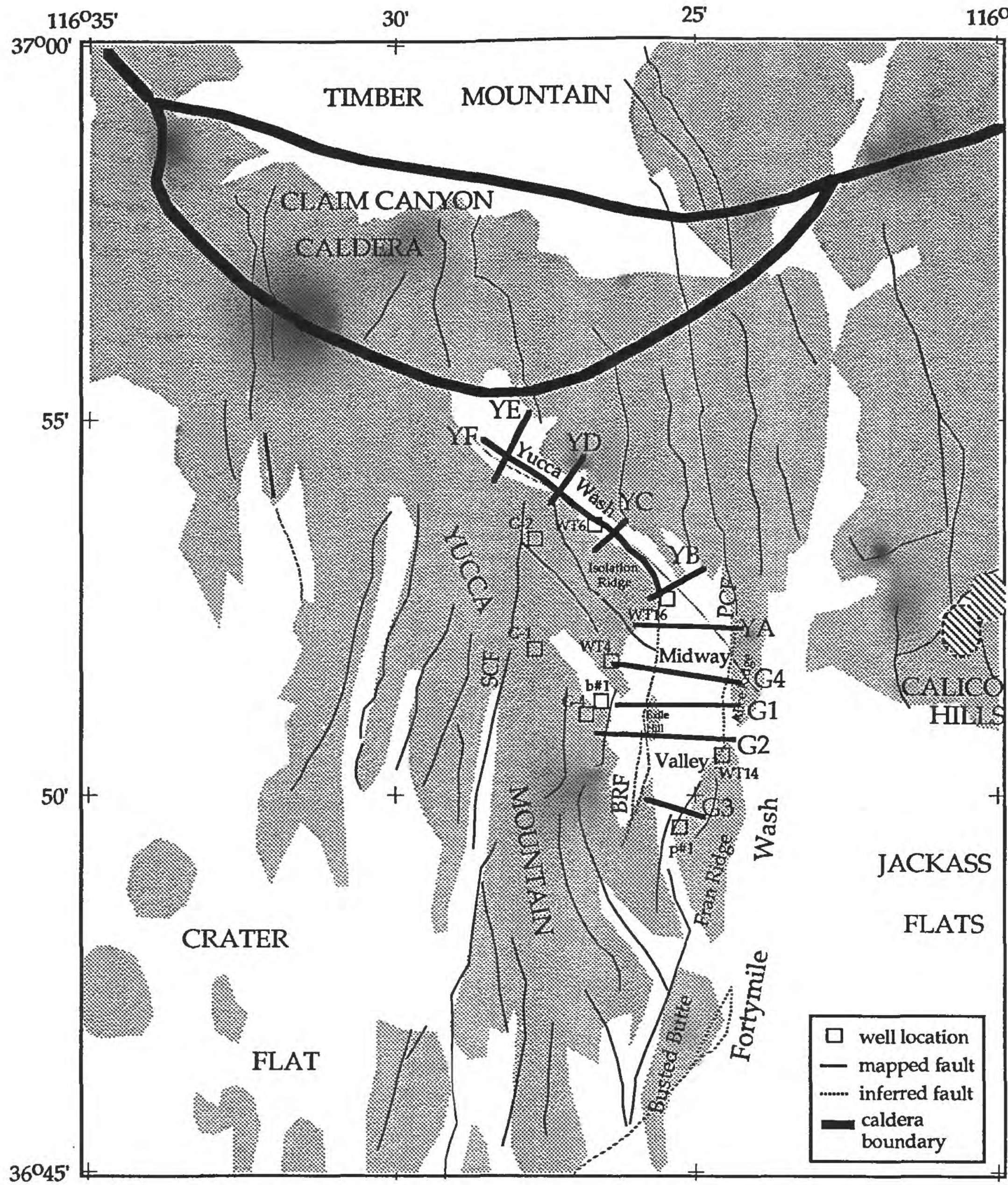

FIguRe 1.-Index map of the study area showing locations of gravity and magnetic profiles across Midway Valley and Yucca Wash. White area, Quaternary alluvium and colluvium; Shaded area, Tertiary volcanic rock; Cross-hatched area, Paleozoic sedimentary rock. BRF, Bow Ridge fault; PCF, Paintbrush Canyon fault; SCF, Solitario Canyon fault. Geology modified from Frizzell and Shulters (1990). 


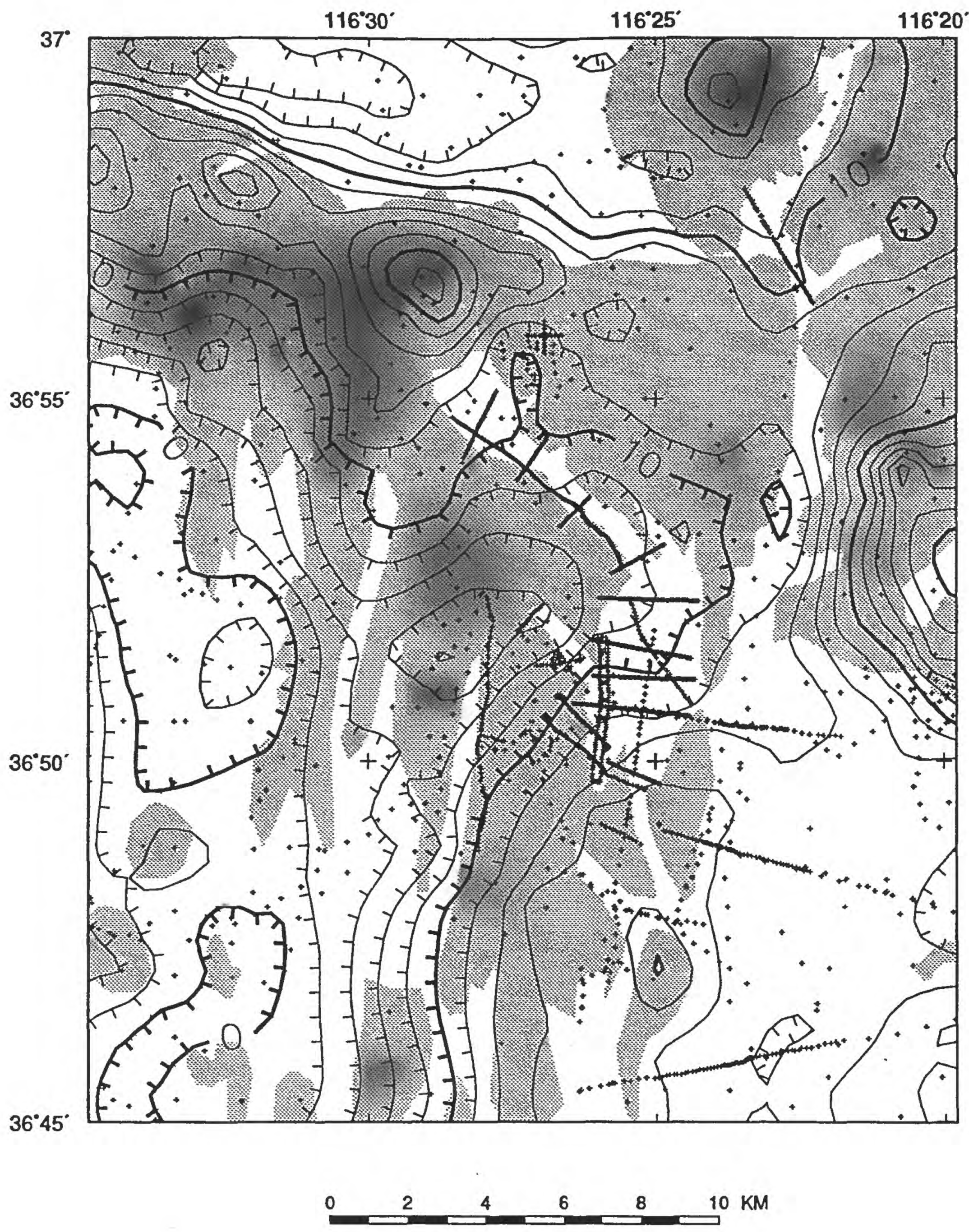

FIGURE 2.-Bouguer gravity map of the study area. Bouguer gravity anomalies reduced for a density of 2.00 $\mathrm{g} / \mathrm{cm}^{3}$. Contour intervals 2 and $10 \mathrm{mGal}$. Shaded area, Tertiary volcanic rock; + , gravity station. 


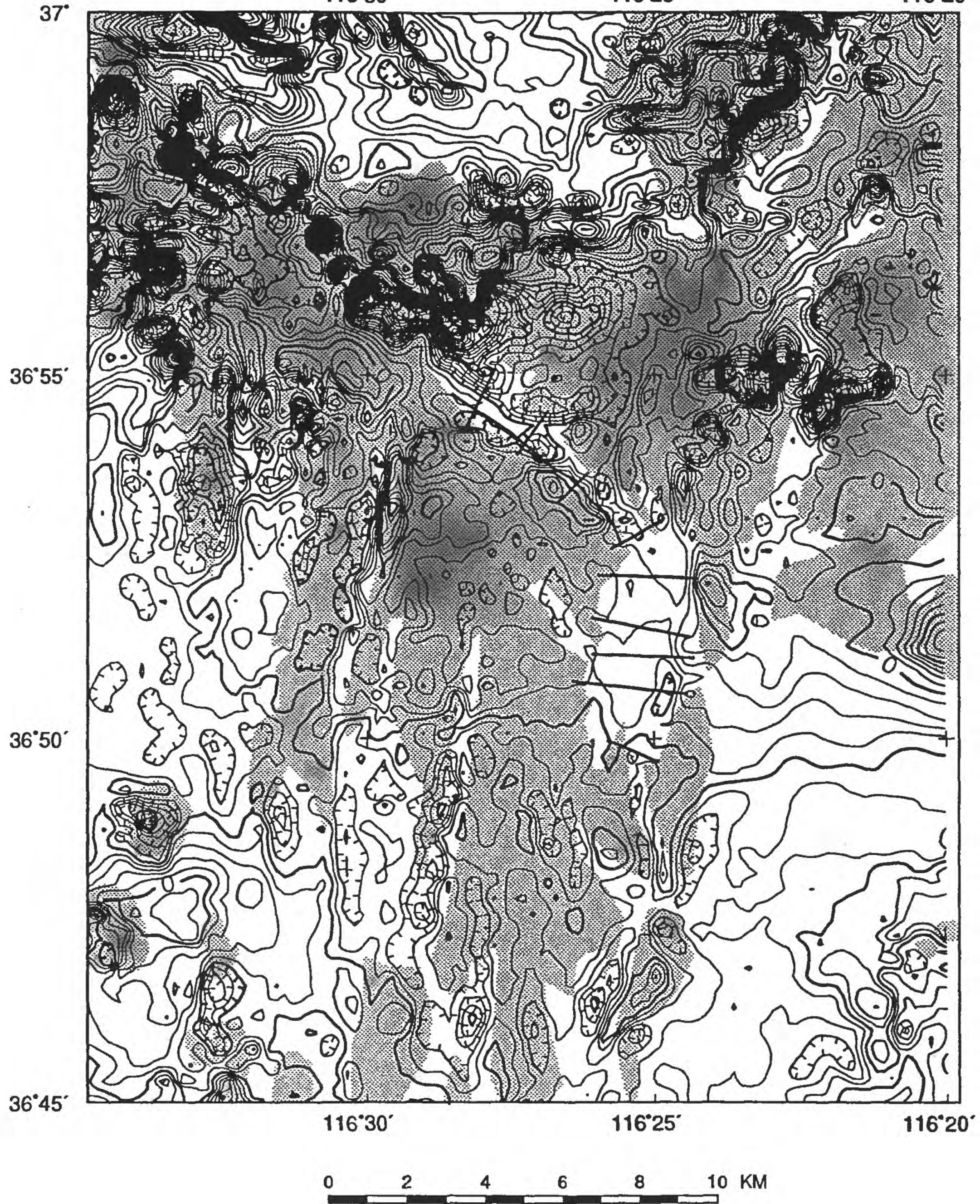

Figure 3.-Magnetic anomaly map of the study area. Shaded area, Tertiary volcanic rocks. Contour intervals 50 and $250 \mathrm{nT}$. 

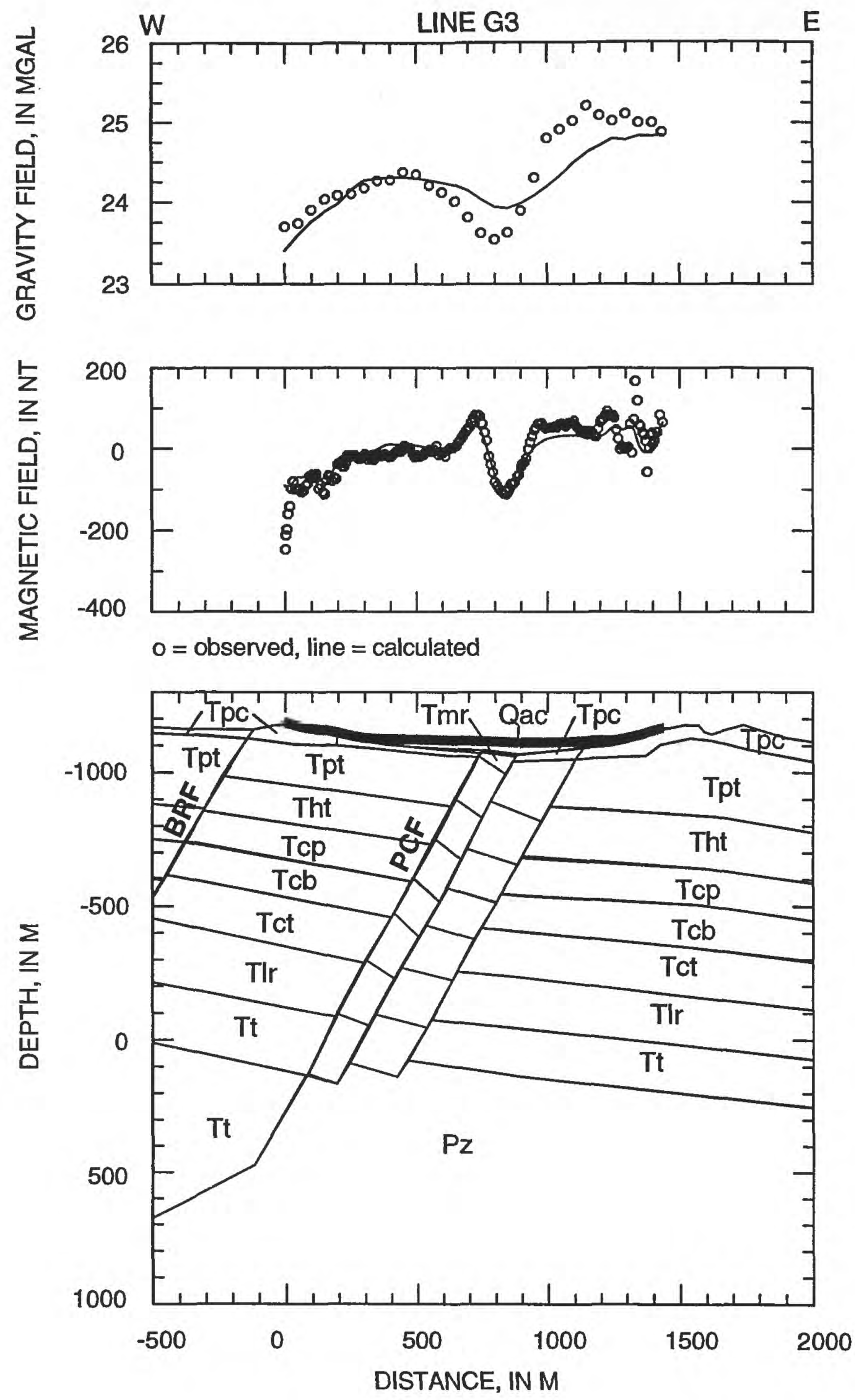

FIGURE 4.-Gravity and magnetic model of line G3. Bouguer gravity anomalies reduced for a density of 2.00 $\mathrm{g} / \mathrm{cm}^{3}$. 

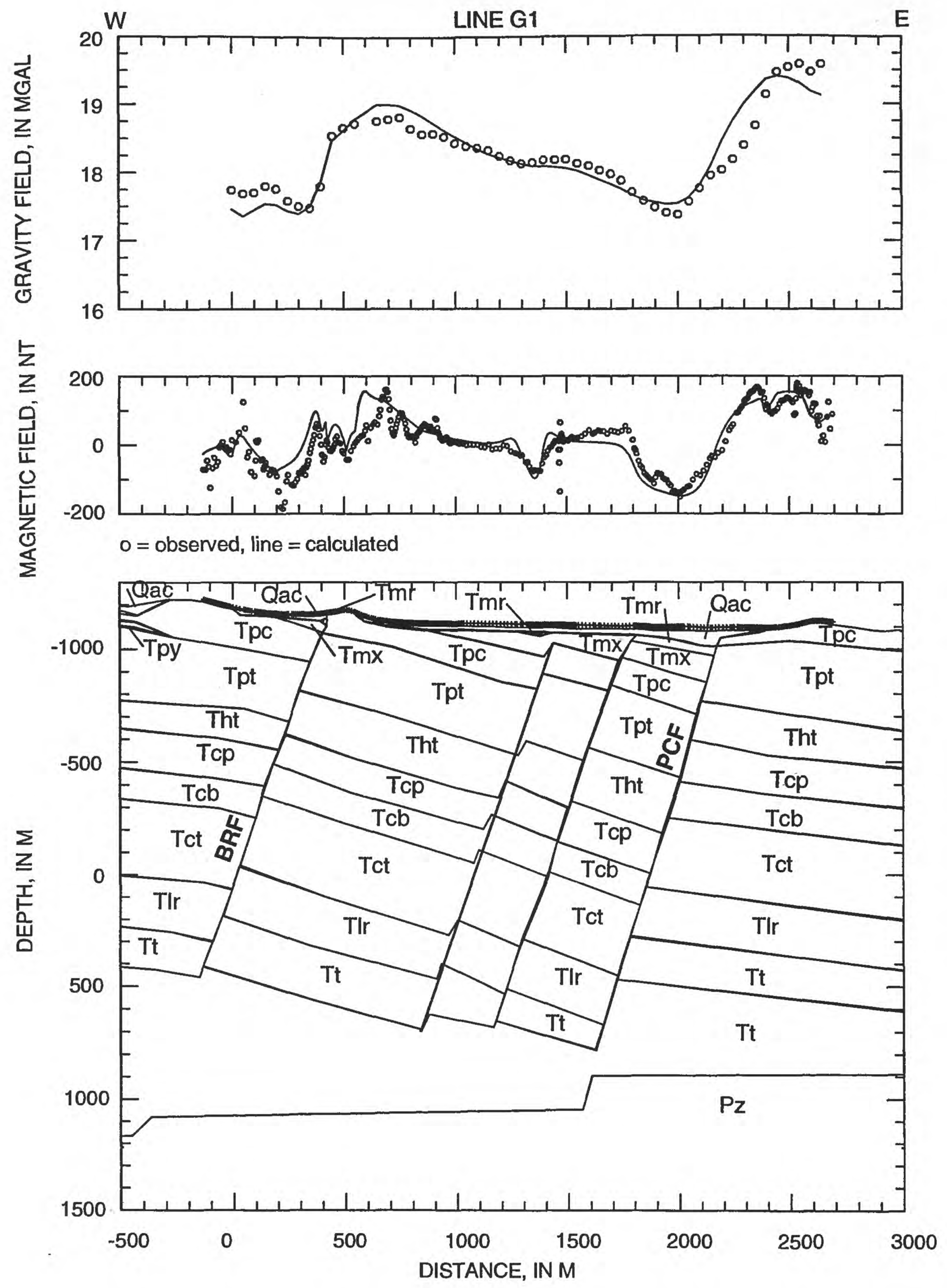

Figure 5.-Gravity and magnetic model of line G1. Bouguer gravity anomalies reduced for a density of 2.00 $\mathrm{g} / \mathrm{cm}^{3}$. 

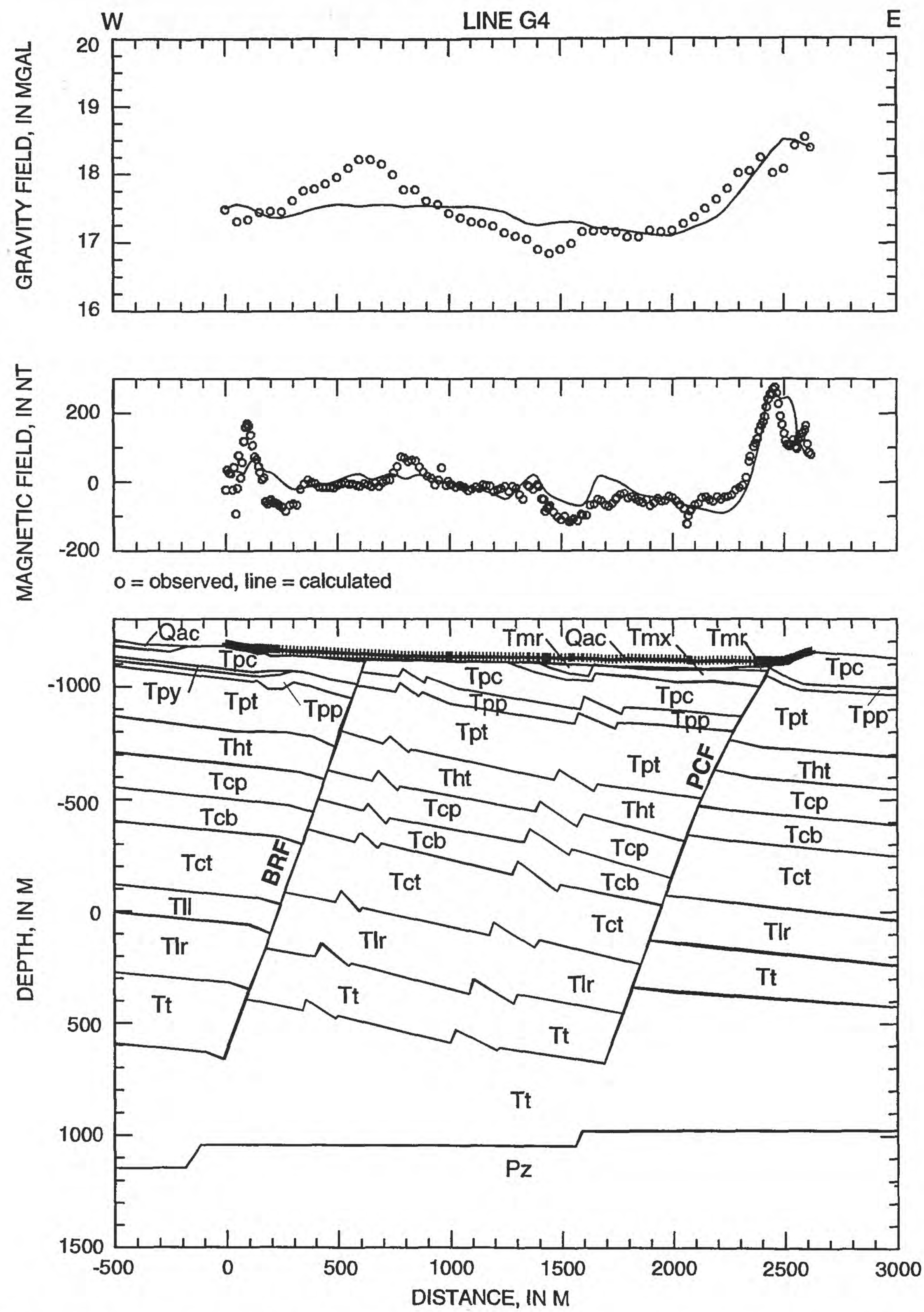

FIgURE 6.-Gravity and magnetic model of line G4. Bouguer gravity anomalies reduced for a density of 2.00 $\mathrm{g} / \mathrm{cm}^{3}$. 

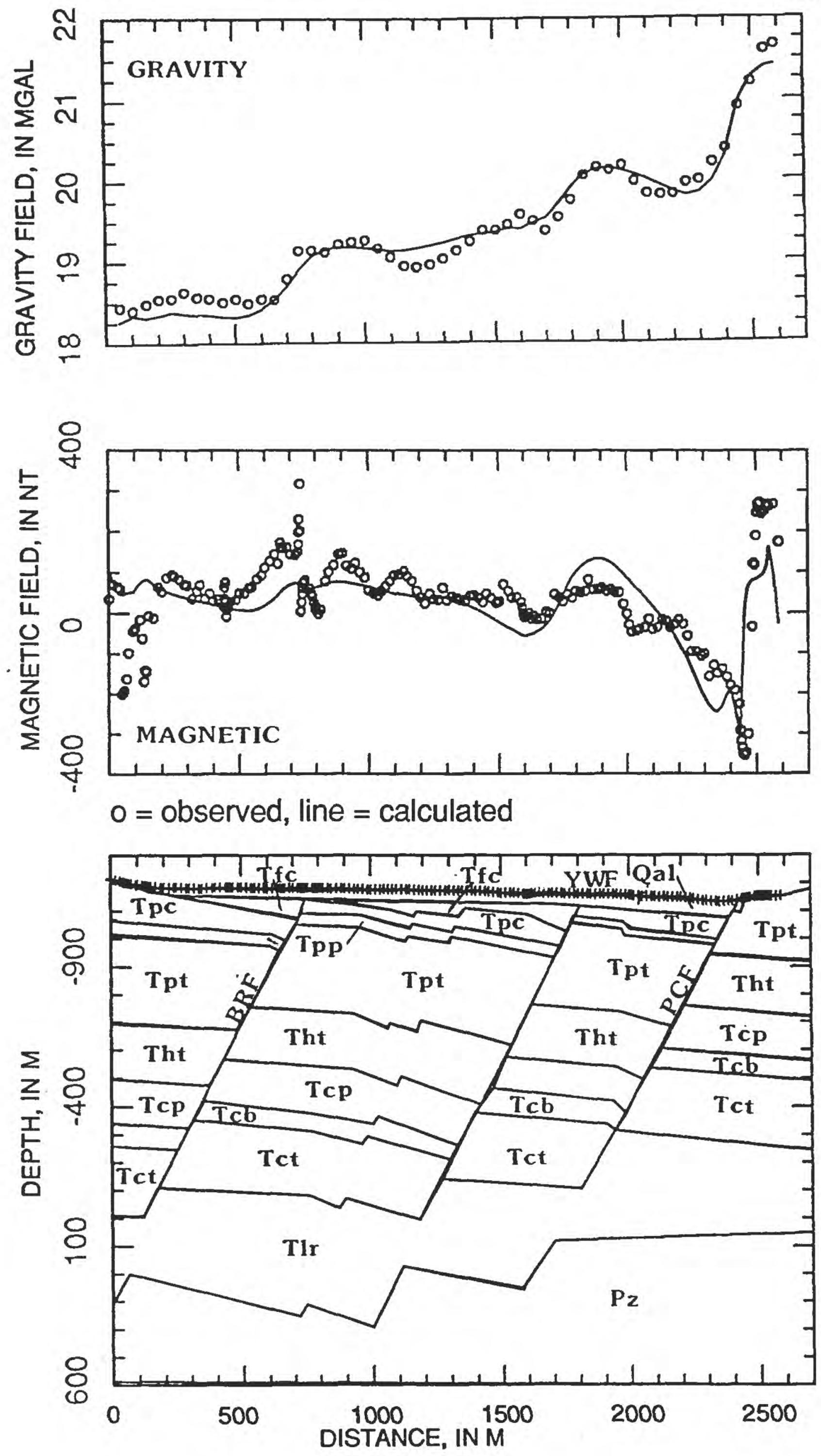

FIGURE 7.-Gravity and magnetic model of line YA. Bouguer gravity anomalies reduced for a density of 2.00 $\mathrm{g} / \mathrm{cm}^{3}$. 

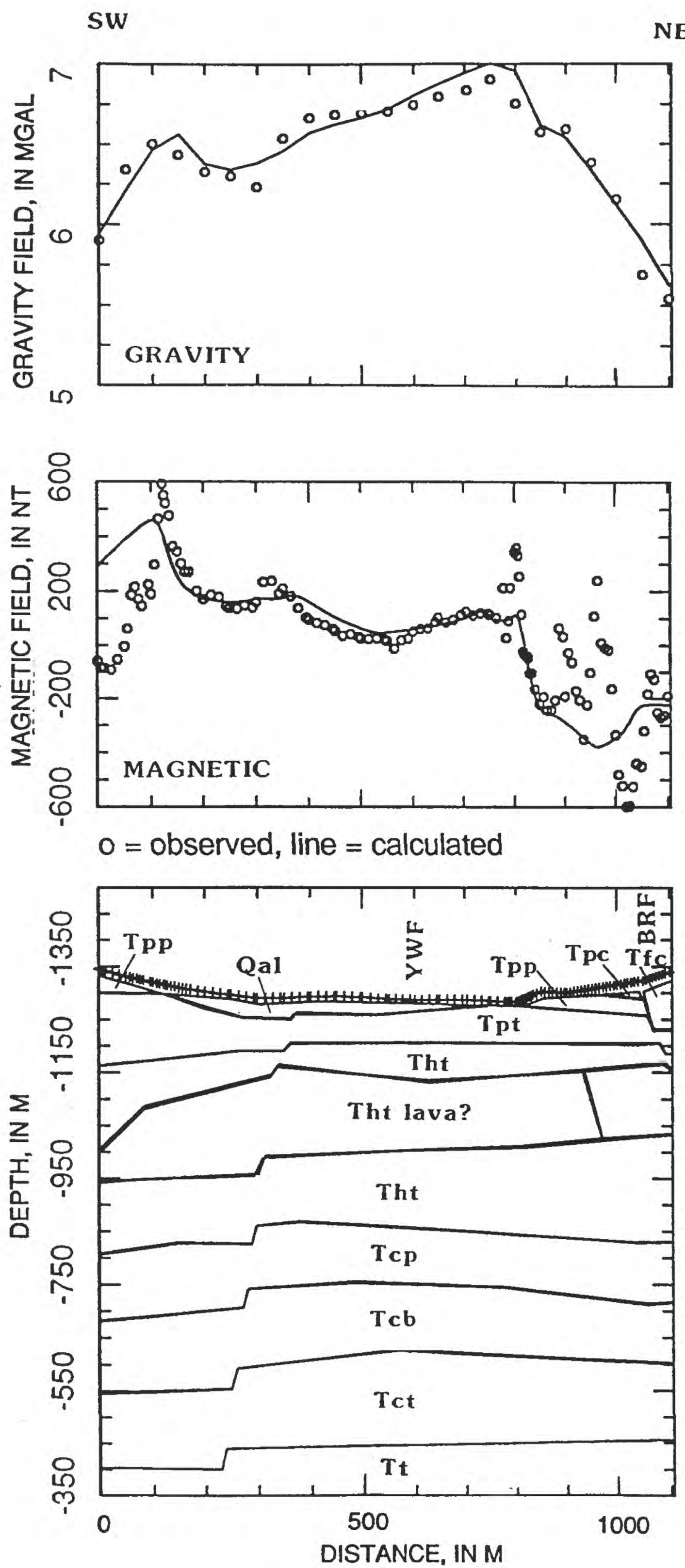

Figure 8.-Gravity and magnetic model of line YC. Bouguer gravity anomalies reduced for a density of 2.00 $\mathrm{g} / \mathrm{cm}^{3}$. 

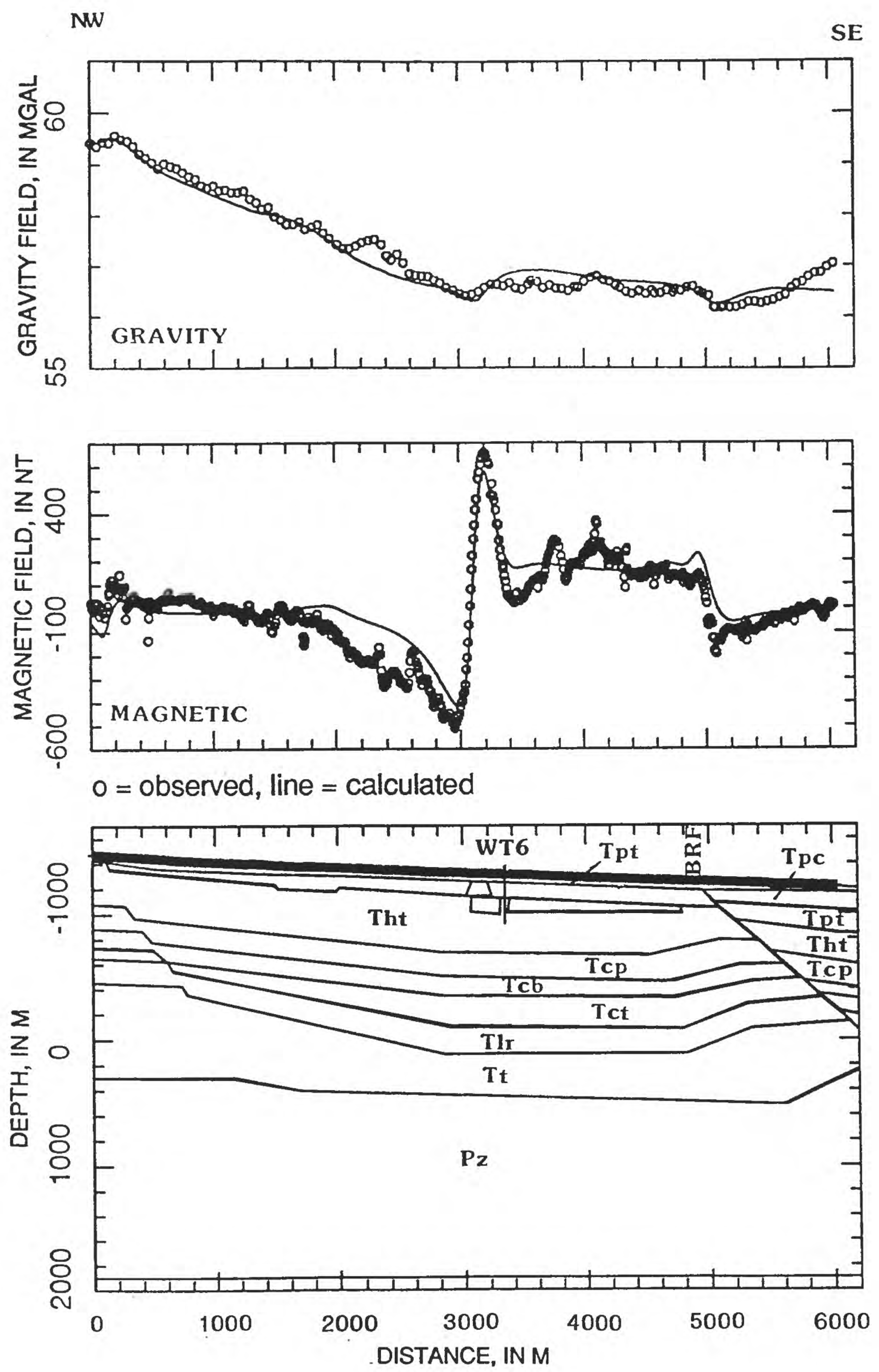

FIGURE 9.-Gravity and magnetic model of line YF. Bouguer gravity anomalies reduced for a density of 2.00 $\mathrm{g} / \mathrm{cm}^{3}$. 